\title{
Antihypertensive Efficacy of LCZ696 (Sacubitril/Valsartan) in Hypertension
}

\author{
Giuliano Tocci \\ Department of Clinical and Molecular Medicine, University of Rome Sapienza, Sant'Andrea Hospital, Rome, Italy; \\ IRCCS Neuromed, Pozzilli, Italy
}

Essential hypertension is a complex clinical condition, characterized by sustained elevation of systolic and/or diastolic blood pressure (BP) levels and an increased risk of developing major cardiovascular (CV) outcomes, mostly including coronary artery disease, stroke, and death. Several studies have also reported that high BP levels are significantly related to AC higher risk of newonset congestive heart failure than normotension and that hypertensive disease (i.e., left ventricular diastolic dysfunction with or without left ventricular remodeling or hypertrophy) may be responsible of the progression from hypertension toward left ventricular systolic dysfunction and clinically evident heart failure, independently of the presence of concomitant conditions and comorbidities [1].

Current guidelines for the clinical management of heart failure have highlighted the progressive nature of the disease, which is summarized by the concept of a "cardiovascular continuum" [2]. This is the reason why preventive strategies aimed at reducing the risk of developing heart failure are currently based on the use of different classes of antihypertensive agents, mostly including drugs inhibiting the renin-angiotensin-aldosterone system, such as angiotensin-converting enzyme inhibitors,

karger@karger.com

(c) 2020 S. Karger AG, Basel

www.karger.com/crd

Karger angiotensin receptor blockers (ARB), and antialdosterone agents [3-5].

Over the last few years, several new drug classes have been developed and tested for the clinical management of hypertension and, thus, for the prevention of hypertension-related $\mathrm{CV}$ diseases, including heart failure. While some classes have shown negative results, some others classes seem to provide favorable results. Among these classes, drug therapy based on LCZ696 (sacubitril/valsar$\tan$ ), a first-in-class angiotensin receptor-neprilysin inhibitor, at different dosages has been demonstrated to improve $\mathrm{CV}$ morbidity and mortality in high-risk patients with heart failure $[6,7]$.

It should be noted, however, that LCZ696 was originally developed for the clinical management of hypertension and that the use of this drug has been shown to provide marked BP reductions both in systolic and in diastolic BP levels [8]. This might have a clinical impact on heart failure patients, since the beneficial effects provided by this drug at both cardiac and vascular levels might be counterbalanced by excessive BP reductions, a reduced cardiac output, hypotension, and fatigue [9].

The article by Hou et al. [10] is a meta-analysis of 12 clinical studies and a total of 6,064 patients, aimed at eval- 
uating the antihypertensive efficacy of LCZ696. Compared with ARB, LCZ696 demonstrated greater reductions in both clinical and 24-h ambulatory systolic/diastolic BP levels. The BP-lowering effect was consistently observed across different clinical studies and was found to be dose-dependent and largely independent of age and baseline $\mathrm{BP}$ values, which ranged within stage 1-2 hypertension. These results confirmed and extended those of previous analyses, which showed similar beneficial effects on $\mathrm{BP}$ reduction [11].

Based on the available evidence, the $\mathrm{BP}$ reductions produced by the use of angiotensin receptor-neprilysin inhibitor can be effectively and safely used for the clinical management of high BP in heart failure patients (albeit outside of the approved indication). On the other hand, this therapeutic effect should be always kept in mind when treating heart failure patients with low BP levels at baseline.

\section{Conflict of Interest Statement}

G.T. has no conflict of interests to disclose.

\section{Funding Sources}

None.

\section{Author Contributions}

G.T. conceived, prepared, and revised this paper in its present form.

\section{References}

1 Garg S, Drazner MH. Refining the classification of left ventricular hypertrophy to provide new insights into the progression from hypertension to heart failure. Curr Opin Cardiol. 2016 Jul;31(4):387-93.

2 Dzau V, Braunwald E. Resolved and unresolved issues in the prevention and treatment of coronary artery disease: a workshop consensus statement. Am Heart J. 1991 Apr; 121(4 Pt 1):1244-63.

3 Mancia G, Fagard R, Narkiewicz K, Redon J, Zanchetti A, Böhm M, et al. 2013 ESH/ESC guidelines for the management of arterial hypertension: the Task Force for the Management of Arterial Hypertension of the European Society of Hypertension (ESH) and of the European Society of Cardiology (ESC). Eur Heart J. 2013 Jul;34(28):2159-219.

4 Pieske B, Tschöpe C, de Boer RA, Fraser AG, Anker SD, Donal E, et al. How to diagnose heart failure with preserved ejection fraction: the HFA-PEFF diagnostic algorithm: a consensus recommendation from the Heart Failure Association (HFA) of the European Society of Cardiology (ESC). Eur Heart J. 2019 Oct;40(40):3297-317.
5 Ponikowski P, Voors AA, Anker SD, Bueno H, Cleland JG, Coats AJ, et al.; ESC Scientific Document Group. 2016 ESC Guidelines for the diagnosis and treatment of acute and chronic heart failure: the Task Force for the diagnosis and treatment of acute and chronic heart failure of the European Society of Cardiology (ESC)Developed with the special contribution of the Heart Failure Association (HFA) of the ESC. Eur Heart J. 2016 Jul; 37(27):2129-200.

6 McMurray JJ, Krum H, Abraham WT, Dickstein K, Køber LV, Desai AS, et al.; ATMOSPHERE Committee Investigators. Aliskiren, enalapril, or aliskiren and enalapril in heart failure. N Engl J Med. 2016 Apr;374(16): 1521-32.

7 Parving $\mathrm{HH}$, Brenner BM, McMurray JJ, de Zeeuw D, Haffner SM, Solomon SD, et al.; ALTITUDE Investigators. Cardiorenal end points in a trial of aliskiren for type 2 diabetes. N Engl J Med. 2012 Dec;367(23):2204-13.
8 Ruilope LM, Dukat A, Böhm M, Lacourcière Y, Gong J, Lefkowitz MP. Blood-pressure reduction with LCZ696, a novel dual-acting inhibitor of the angiotensin II receptor and neprilysin: a randomised, double-blind, placebo-controlled, active comparator study. Lancet. 2010 Apr;375(9722):1255-66.

9 Volpe M, Tocci G, Battistoni A, Rubattu S. Angiotensin II Receptor Blocker Neprilysin Inhibitor (ARNI): New avenues in cardiovascular therapy. High Blood Press Cardiovasc Prev. 2015 Sep;22(3):241-6.

10 Hou F, Wang Z, Yan R, Geng Q. Effects of LCZ696 on blood pressue in patients with hypertension: a meta-analysis of randomized controlled trials. Cardiology. Forthcoming 2020.

11 Zhao Y, Yu H, Zhao X, Ma R, Li N, Yu J. The Effects of LCZ696 in Patients With Hypertension Compared With Angiotensin Receptor Blockers: A Meta-Analysis of Randomized Controlled Trials. J Cardiovasc Pharmacol Ther. 2017 Sep;22(5):447-57. 